\title{
IMPLEMENTASI KEBIJAKAN PNPK TATA LAKSANA THALASSEMIA DI KABUPATEN SUBANG
}

\author{
Wanti Dewanti, Ira Irawati, Mas Halimah \\ Departemen Administrasi Publik, Universitas Padjajaran, Indonesia \\ ${ }^{1}$ wanti17001@mail.unpad.ac.id
}

\begin{abstract}
The increase of patients suffering Thalassemia especially in Subang district pushed the estabilishment of the organization named POPTI. The objective of this study is to analyse the role of POPTI in implementing handling policy PNPK of Thalassemia patients. The research method used is qualitative with conducting semi structured interview, observation, and documentation research. The result of this research shows that the role of POPTI is significant important in handling Thalassemia patients, yet the role has not fully gone well. There is still lack of coordination and communication between members and related agencies. This is the reason for implementing the handling policy of Thalassemia patients in Subang district, which hasn't been optimal. Therefore, it is necessary to improve the system and awareness of chairman and members to coordinate and collaborate for handling Thalassemia patients in Subang district.
\end{abstract}

Keywords : Public Policy, Implementation Policy, Thalassemia, POPTI.

\begin{abstract}
ABSTRAK
Salah satu penyakit kronik di Indonesia ialah Thalassemia. Meningkatkannya pasien thalassemia khususnya di Kabupaten Subang, mendorong berdirinya organisasi bernama POPTI. Tujuan penelitian ini untuk menganalisis peranan POPTI dalam implementasi kebijakan PNPK tata laksana thalassemia. Metode yang digunakan yaitu metode penelitian kualitatif dengan melakukan wawancara semi struktur, observasi, dan studi dokumentasi. Hasil penelitian menunjukkan bahwa peranan POPTI sangat penting untuk penanganan pasien thalassemia, namun peran ini belum sepenuhnya berjalan dengan baik. Masih kurangnya kordinasi serta komunikasi antar anggota dan dinas terkait, inilah yang menjadi penyebab implementasi kebijakan penanganan pasien thalassemia di Kabupaten Subang berlum optimal. Oleh karena itu, perlu adanya perbaikan sistem dan kesadaran dari ketua dan anggota POPTI untuk melakukan kordinasi dan kerjasama untuk penanganan pasien thalassemia di Kabupaten Subang.
\end{abstract}

Kata Kunci: Kebijakan Publik, Implementasi Kebijakan, Thalassemia, POPTI 


\section{PENDAHULUAN}

Thalassemia merupakan salah satu penyakit kronik di Indonesia. Prevalensi penduduk dunia yang memiliki kelainan thalassemia ini sekitar 7-8 persen. Sehingga, di Indonesia diperkirakan terdapat 20 juta penduduk yang membawa kelainan gen ini. Di Kabupaten Subang yang berada di provinsi Jawa Barat hampir setiap Kecamatan terdapat pasien Thalassemia.
Kecamatan Subang menduduki peringkat pertama jumlah pasien terbanyak yaitu 15 orang. Serta jumlah seluruh pasien yang terdata di Kabupaten Subang sebanyak 128 orang. Pasien thalassemia mayor hidupnya dapat dipertahankan dengan transfusi darah yang dapat menimbulkan berbagai efek yaitu tertularnya penyakit lewat transfusi seperti penyakit hepatitis B,C, dan HIV. Selain itu pemberian transfusi darah

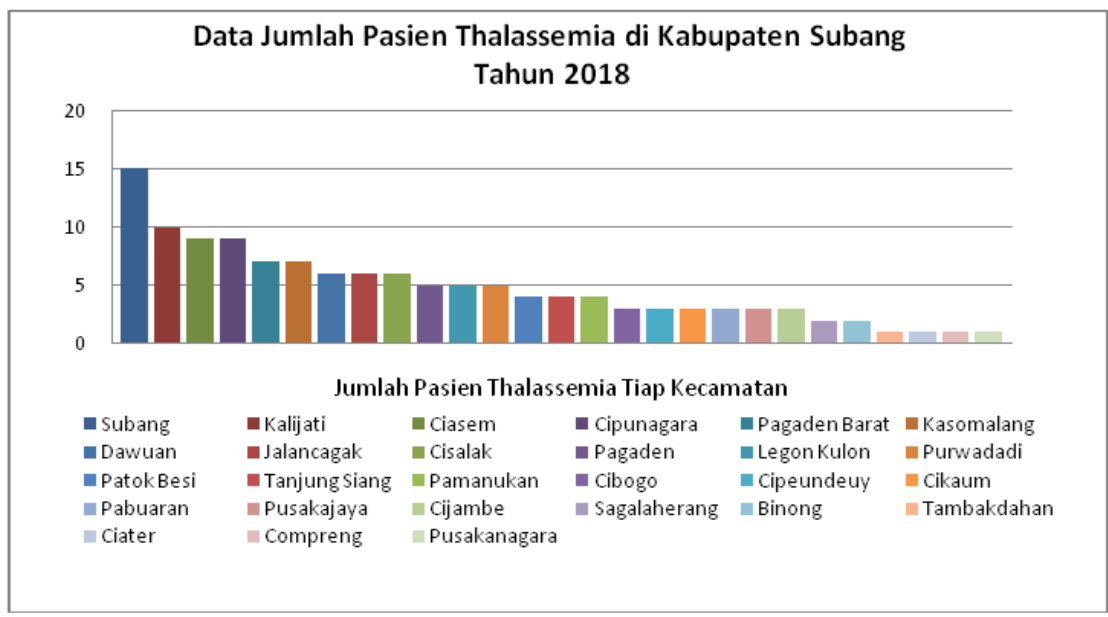

Gambar 1

Data Jumlah Pasien Thalassemia di Kabupaten Subang Tahun 2018 (Sumber : POPTI,2018)

Pada gambar 1 dapat di lihat bahwa Kabupaten Subang memiliki 30 Kecamatan, dari beberapa kecamatan tersebut, hanya 3 kecamatan yang tidak ditemukan pasien thalassemia yaitu Sukasari, Blanakan dan Serang panjang. Hal ini berarti $90 \%$ setiap kecamatan di Kabupaten Subang terdapat pasien thalassemia. Dan tidak hanya itu, yang berulang-ulang dapat menimbulkan komplikasi hemosiderosis dan hemokromatis yang menimbulkan penimbunan zat besi dalam jaringan tubuh sehingga dapat menyebabkan kerusakan organ-organ tubuh seperti: hati, limpa, ginjal, jantung, tulang dan pankreas. Tanpa transfusi yang memadai pasien thalassemia mayor 
akan yang dialami oleh pasien thalassemia mayor yaitu luka terbuka di kulit (ulkus, borok), pembesaran limpa, batu empedu, badan berwarna kuning, lemah, letih, lesu, lemas, dan jantung berdebar-debar. Hal ini juga dapat menyebabkan kematian pada pasien (Fahrudin \& Mulyani, 2011).

Dampak dari penyakit thalassemia ini menyebabkan kecemasan pada orang tua dan anak. Maka dari itu perlunya peranan sesama para orang tua yang anaknya mengidap penyakit thalassemia. Peranan ini diperlukan untuk support system dalam memotivasi dan memberi pengetahuan mengenai penanganan pasien thalassemia. Maka terbentuklah suatu organisasi yaitu Perhimpunan Orang Tua Penderita Thalassemia (POPTI) dibawah Yayasan Thalassemia Indonesia (YTI).

Munculnya masalah kesehatan masyarakat ini, mendapat respon dari pemerintah dengan dikeluarkannya kebijakan yang tertuang dalam Keputusan Menteri Kesehatan Republik Indonesia Nomor HK.01.07/MENKES/1/2018 Tentang Pedoman Nasional Pelayanan Kedokteran Tata Laksana Thalasemia yang selanjutnya disebut PNPK Tata Laksana Thalassemia. Artikel ini lebih memfokuskan peranan POPTI sebagai kelompok sasaran (target group) dalam implementasi kebijakan PNPK Tata Laksana Thalassemia di Kabupaten Subang.

Kebijakan publik terdiri dari dua kata yang digabungkan. Penggabungan kedua kata itu menghasilkan sebuah konsep dan nilai-nilai, norma, etika, dan ilmu pengetahuan. Untuk konsep awal akan dijelaskan makna dari kebijakan.

Kebijakan atau yang sering dipersamakan maknanya dengan kata policy adalah sebuah kata yang dalam implikasinya bisa digunakan secara luas atau makro atau sempit atau terbatas ruang lingkupnya (mikro). Kebijakan juga terkait dengan sebuah kewenangan, namun ia memiliki ruang lingkup atau keterbatasan sesuai dengan tugas dan fungsi yang diembannya (Rusli,2013:30). Secara singkat, Hasswel \& Kaplan (Rusli,2013) mengatakan bahwa "Policy: A Project program of goals, value, and practices". Dapat diartikan bahwa kebijakan merupakan suatu program pencapaian tujuan, nilai-nilai, dan praktek-praktek terarah.

Sedangkan makna kedua yaitu publik. Dalam bahasa Yunani istilah publik seringkali dipadankan dengan 
istilah dalam bahasa inggris yaitu kata common bermakna hubungan antar individu. Dalam kontek ini kata publik seringkali dikonsepkan sebagai sebuah ruang yang berisi aktivitas manusia yang dipandang perlu untuk diatur/diintervensi oleh pemerintah/aturan sosial/setidaknya oleh tindakan bersama (Rusli,34:2013). Dalam perspektif ini kata publik kemudian disandikan dengan kata kebijakan sehingga membentuk sebuah pengertian ilmiah.

Anderson (2000) menyatakan kebijakan publik sebagai: “A relative stable, purposive course of action followed by an actor or set of actors in dealing with set a problem or matter of concern". Dapat diartikan bahwa kebijakan publik sebagai serangkaian tindakan yang mempunyai tujuan tertentu yang diikuti dan dilaksanakan oleh pelaku atau sekolompok pelaku guna memecahkan masalah tertentu.

Sedangkan, menurut Mulyadi (2015):

"Kebijakan publik merupakan salah satu dimensi pokok dalam ilmu dan praktik Administrasi Publik. Sebagai salah satu unsur penting dalam Administrasi Publik, Kebijakan Publik dianalogikan fungsinya sama dengan fungsi otak pada tubuh manusia, karena melalui instrument ini, segala aktivitas kehidupan bernegara, dan bermasyarakat mulai dilakukan oleh birokrasi, plus pihak swasta dan masyarakat."

Dari berbagai pendapat para ahli, dapat ditarik kesimpulan bahwa kebijakan publik merupakan serangkaian tindakan yang harus dilakukan ataupun tidak dilakukan oleh pelaku atau sekolompok pelaku yang mempunyai tujuan untuk memecahkan masalah.

Pencapaian tujuan kebijakan publik tidak dapat berjalan jika tidak diimplementasikan. Dapat dikatakan bahwa tanpa implementasi, kebijakan publik adalah daftar keinginan. Menurut Van Meter dan Van Horn (1975) menyatakan bahwa: "Policy implementation encompasses those actions by public or private individuals (or groups) that are directed at the achievement of objectives set forth in prior policy decisions." Dapat diartikan bahwa implementasi kebijakan meliputi tindakan-tindakan oleh individu umum atau pribadi/kelompok yang diarahkan pada pencapaian tujuan yang ditetapkan dalam keputusan kebijakan sebelumnya. 
Kemudian Howlet dan Ramesh (2003:185) menyatakan, "its is defined as the process whereby programs or policies are carried out, the translation of plans into practice". Hal ini dapat diartikan bahwa implementasi kebijakan adalah proses pelaksanaan programprogram atau kebijakan-kebijkan yang merupakan penerjemahan dari rencanarencana kedalam praktek.

Kegiatan implementasi itu bukan sebuah tujuan sehingga ketika kegiatan sudah dilakukan bukan berarti pelaksanaan kegiatan sudah berhasil dengan baik. ukuran keberhasilan itu harus diuji dengan model atau mekanisme tersediri berikut tolok ukur atau parameternya.

Menurut Smith (Rusli,2013) terdapat empat variabel yang berperan penting dalam proses implementasi kebijakan publik, yaitu:

a. Kebijakan yang diidealkan (Idealized policy): yakni pola-pola interaksi ideal yang telah mereka definisikan dalam kebijakan yang berusaha diinduksikan.

b. Kelompok sasaran (Target groups) yaitu mereka (orang-orang) yang paling langsung diperngaruhi oleh kebijakan dan yang harus mengadopsi pola-pola interaksi sebagaimana yang diharapkan oleh perumus kebijakan.

c. Organisasi

Pelaksana

(Implementing organization) yaitu badan-badan pelaksana atau unitunit birokrasi pemerintah yang bertanggung jawab dalam implementasi kebijakan.

d. Faktor Lingkungan (Environmental factor) yaitu unsur-unsur dalam lingkungan yang mempengaruhi atau dipengaruhi oleh implementasi kebijakan seperti aspek budaya, sosial, ekonomi, dan politik.

Model Smith ini merupakan model bawah atas yang sering disebut dengan istilah model implementasi kebijakan Bottom Up. Model Bottom up adalah model yang memandang proses sebagai sebuah negosiasi dan pembentukan konsensus. Lebih lanjut Parsons (2006) model pendekatan bottom up menekankan pada fakta bahwa implementasi di lapangan memberikan keleluasan dalam penerapan kebijakan. Ahli kebijakan dalam perspektif bottom up adalah Smith. Untuk lebih jelasnya dapat lihat pada gambar 2.

Menurut Smith (Islamy,2001), implementasi kebijakan dipandang sebagai suatu proses atau alur. Model 
ini memandang proses implementasi kebijakan dari proses kebijakan dari perspektif perubahan sosial dan politik, dimana kebijakan yang dibuat oleh pemerintah bertujuan untuk mengadakan perbaikan atau perubahan dalam masyarakat sebagai kelompok sasaran. Berdasarkan penjelasan tersebut penelitian ini menggunakan teori implementasi kebijakan dari Smith ini.

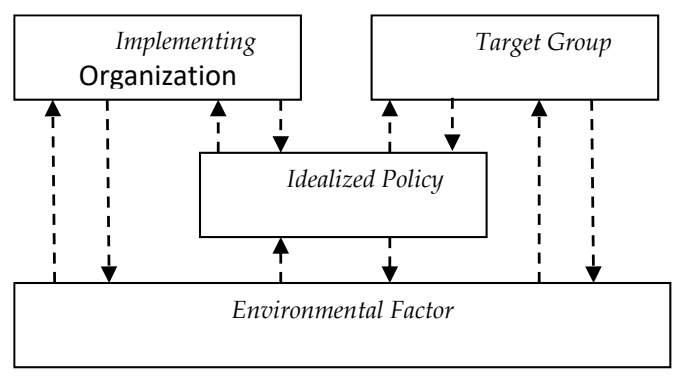

Gambar 2. Model Implementasi

Smith (1973). Sumber: Smith (1973)

\section{METODE}

Metode penelitian yang digunakan pada penelitian ini ialah metode penelitian deskriptif kualitatif. Adapun teknik pengaumpulan data dalam penelitian ini yaitu:

1. Wawancara, yaitu dengan mendatangi langsung dan melakukan tanya jawab secara semistruktur dengan pihak terkait dalam peneletian ini yaitu ketua POPTI Subang, anggota POPTI, dan perawat ruang thalassemia di RSUD Kab.Subang.

2. Observasi, dilakukan melalui pengamatan secara langsung dengan maksud untuk mendukung data dalam penelitian ini.

3. Studi dokumentasi, yaitu dengan mempelajari data-data, informasiinformasi yang berhubungan dengan peranan POPTI dalam implementasi kebijakan penanganan pasien thalassemia di Kab.Subang yang diakses melalui media internet dan media lainnya.

\section{HASIL DAN PEMBAHASAN}

Organisasi masyarakat bernama POPTI ( Persatuan Orang Tua Pasien Thalassemia). Sejarah singkat POPTI, awal mulanya beberapa orang tua pasien bertemu di rumah sakit saat mengantarkan anak-anaknya untuk transfusi darah yaitu pada tahun 1983, dan dokter ahlinya pada saat itu Prof. Dr. dr. Iskandar Wahidiyat, $\operatorname{SpA}(\mathrm{K})$ selalu mengatakan kepada orang tua pasien, kenapa tidak didirikan Parent Association seperti di luar negeri. Akhirnya atas prakarsa Prof. Dr. dr. Iskandar Wahidiyat, $\operatorname{SpA}(\mathrm{K})$ dengan beberapa orang tua pasien Thalassemia pada tanggal 27 Mei 1984 dibentuk suatu wadah yang namanya 
Perhimpunan Orang Tua Pasien Thalasaemia Indonesia (POPTI).

Dengan maksud dan tujuannya adalah meringankan beban orang tua pasien, media komunikasi sesama orang tua pasien Thalasaemia, dan mengurangi meningkatnya pasien Thalassemia. Untuk mencapai maksud dan tujuan diatas, maka akan dilakukan langah-langkah usaha yang terpadu, yang antara lain mencakup:

1. Bersama-sama dengan Yayasan mengupayakan pengadaan darah, peralatan medis dan obat-obatan yang diperlukan atas dasar keterjangkauan secara tepat waktu dan berkesinambungan.

2. Mendirikan Pusat Kegiatan Thalassemia (Thalassemia Center) dibeberapa daerah seperti di Jakarta.

Memasuki usianya yang ke tiga, Perhimpunan ini pada tanggal $27 \mathrm{Mei}$ 1987 telah mendirikan Yayasan Thalassemia Indonesia. Yang mana Yayasan ini didirikan atas prakarsa para pengurus dan para pendiri dari Perhimpunan untuk memudahkan pencarian dana bagi para pasien. Kegiatan yang dilaksanakan :

1. Mengadakan pertemuan anggota dalam setahun 3 kali.
2. Melakukan kegiatan donor darah.

3. Audensi dengan para menteri.

4. Mencari dana dengan mengadakan Malam Dana bekerjasama dengan mahasiswa.

Tidak mudah bagi orang tua anak penyandang thalasemia yang masih awam dengan penyakit ini, mereka akan cenderung mengunci anaknya di rumah. karena menyadari adanya kelainan fisik pada anak dan khawatir keluarga mendapatkan cemoohan dan ejekan dari masyarakat tempat mereka tinggal. Bagi anak sendiri, disaat menyadari bahwa secara fisik ia berbeda dengan anak pada umumnya, ia akan merasa rendah diri dan mulai menarik diri. Bahkan di beberapa kasus, banyak anak penyandang thalassemia yang dikucilkan oleh teman-temannya karena secara fisik ia berbeda dari mereka dan akibat lebih jauh dari dikucilkan tersebut adalah anak berhenti bersekolah sebelum waktunya.

Hal ini akan menimbulkan stressor bagi keluarga yang memiliki anak dengan thalasemia, keluarga memiliki fungsi sebagai pemeliharaan kesehatan, memberikan perawatan kesehatan yang bersifat preventif dan secara bersama sama merawat anggota keluarga yang sakit. Kemampuan 
keluarga dalam memberikan asuhan kesehatan akan mempengaruhi tingkat kesehatan keluarga dan individu, tingkat pengetahuan keluarga terkait konsep sehat sakit akan mempengaruhi prilaku keluarga dalam menyelesaikan masalah kesehatan keluarga. (Harmoko, 2012). Inilah yang mendukung adanya POPTI sebagai organisasi untuk memotivasi keluarga pasien.

Peranan ini juga didukung dengan adanya AD-ART POPTI dimana disebutkan bahwa maksud dan tujuan didirikannya organisasi POPTI ialah untuk meringankan beban orang tua para orang tua penderita penyakit thalassemia, sebagai media komunikasi diantara sesama orang tua penderita, dan mengurangi peningkatan penderita penyakit thalassemia. Selain itu juga, POPTI dapat menjalin hubungan yang serasi dengan para dokter dan rumah sakit pusat maupun daerah.

POPTI terdapat dibeberapa wilayah di Jawa Barat, terdapat 17 titik cabang POPTI. Yaitu Bandung, Bogor, Garut, Tasikmalaya, Cirebon, Sukabumi, Bekasi, Sumedang, Karawang, Ciamis, Cianjur, Kuningan, Majalengka, Depok, Tanggerang, Banjar, dan Subang. (sumber: POPTI Subang).
Dalam artikel ini peneliti memfokuskan lokasi pada POPTI Subang. POPTI Subang dipimpin oleh ketua yang merupakan perwakilan dari para orang tua pasien thalassemia. Ketua ini memiliki kekuasaan untuk mengelola dan mengajak para orang tua untuk sama-sama berjuang dalam pengobatan anak thalassemia.

Menurut Smith (Rusli,2013) terdapat empat dimensi implementasi kebijakan yaitu kebijakan ideal, organisasi pelaksana, kelompok sasaran, dan faktor lingkungan. Pada penelitian ini, peneliti fokus melihat pada dimensi kelompok sasaran (target group). Kelompok yang menjadi sasaran implementasi kebijakan yang diharapkan dapat mengadopsi rumusanrumusan dari kebijakan PNPK tata laksana thalassemia. Kelompok sasaran pada kebijakan PNPK ini ialah pasien thalassemia yang termasuk kedalam organisasi Popti. Popti merupakan perkumpulan para orang tua pasien thalassemia.

Capaian hasil implementasi kebijakan PNPK tata laksana thalassemia yang dilaksanakan oleh Dinas Kesehatan, Rumah Sakit, dan PMI tergantung juga dari kelompok sasaran atau pasien thalassemia dan 
Popti. Kelompok sasaran merupakan suatu gambaran dari harapan masa depan yang ingin dicapai, dimana pasien thalassemia dapat hidup lebih baik lagi dengan menjalani pengobatan yang terbaik. Khususnya dalam pelayanan kesehatan, seperti transfusi darah dan ketersediaan obat.

Keberadaan kelompok sasaran berpengaruh terhadap implementasi kebijakan pelayanan kesehatan, yang tidak terlepas dari faktor tingkat pemahaman, sosialisasi kebijakan, keinginan bekerjasama, kesadaran berkomitmen, sikap dan perilaku.

Peran POPTI dalam penanganan pasien thalassemia antara lain : melakukan pendataan data base bagi

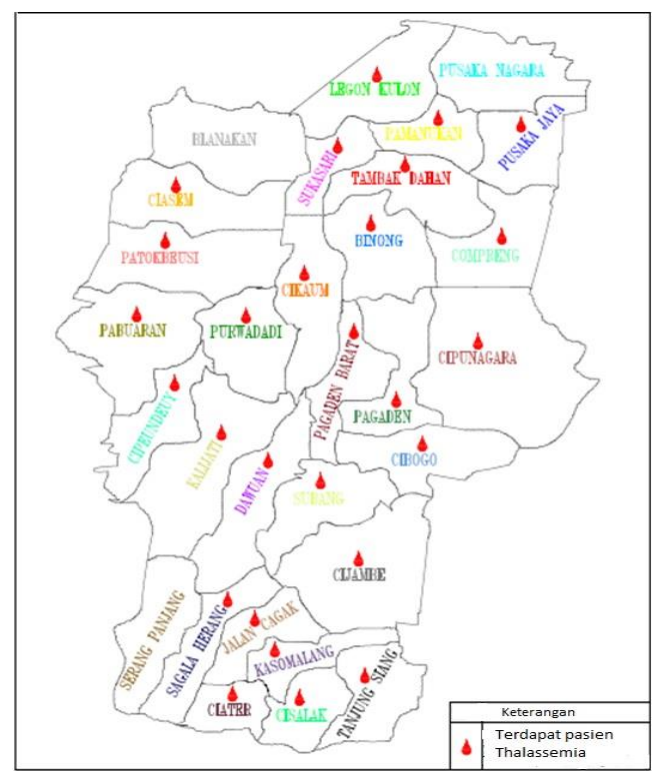

Gambar 3. Peta Penyebaran Pasien Thalassemia setiap Kecamatan Di

Kabupaten Subang (Sumber : POPTI

Subang, 2018) seluruh pasien thalassemia mayor di Indonesia yang akan mendapatkan jaminan kesehatan, memberikan kartu anggota YTI untuk tanda bahwa pasien sudah termasuk anggota YTI, dan membantu mengawasi dan memonitor kelancaran pelayanan pengobatan Thalassemia di Rumah Sakit, serta meemberikan dukungan kepada keluarga dan pasien thalassemia.

Gambaran umum yang menunjukkan besarnya pasien thalassemia di Kabupaten Subang penting sebagai perhatian khusus bahwa penyebarannya sudah kian tinggi.

Dari gambar 3, peta tersebut terlihat bahwa hampir setiap kecamatan di Kabupaten Subang terdapat pasien Thalassemia. Penyebaran ini yang seharusnya menjadi perhatian penting bagi pemerintah dan POPTI setempat. Disinilah salah satunya peran aktor dalam penanganan pasien thalassemia yaitu POPTI.

Pemerintah mengeluarkan kebijakan melalui Keputusan Menteri Kesehatan Republik Indonesia Nomor HK.01.07/MENKES/1/2018 Tentang Pedoman Nasional Pelayanan Kedokteran Tata Laksana Thalasemia. Pedoman Nasional Pelayanan Kedokteran Tata Laksana Thalassemia 
yang selanjutnya disebut PNPK Tata

Laksana Thalassemia merupakan pedoman penyusunan standar operasional penanganan pasien thalassemia. Pada lampiran keputusan tersebut terdapat point-point bagi POPTI untuk memberi dukungan (support group) thalasseia agar anak dan keluarga dapat bertukar pengalaman dan saling menguatkan dengan anak dan keluarga lainnya.

Tujuan pemerintah mengeluarkan kebijakan tidak akan tercapai apabila tidak di implementasikan dengan baik, begitupula halnya Keputusan Menteri Kesehatan Republik Indonesia Nomor HK.01.07/MENKES/1/2018 Tentang Pedoman Nasional Pelayanan Kedokteran Tata Laksana Thalassemia.

POPTI sebagai organisasi kelompok sasaran dalam implementasi kebijakan Keputusan Menteri Kesehatan Republik Indonesia Nomor HK.01.07/MENKES/1/2018 Tentang Pedoman Nasional Pelayanan Kedokteran Tata Laksana Thalasemia. Namun, berdasarkan pemikiran penulis, POPTI bukan hanya sebagai kelompok sasaran yang menerima implementasi kebijakan tersebut. POPTI juga sebagai organisasi pelaksana dalam penanganan pasien thalassemia.
Berdasarkan hasil wawancara (25

Mei 2019) dengan Ketua POPTI Subang, mengatakan bahwa telah mengetahui kewajibannya dalam membantu pelayanan pasien thalassemia. Sehingga dalam implementasi kebijakan penanganan pasien thalassemia secara umum sudah memahami apa yang menjadi kewajiban. Seperti contoh kegiatan rutin yang dilakukan POPTI Subang yaitu dilaksanakan 3-6 bulan sekali. Dalam pertemuan ini Ketua POPTI memotivasi para orang tua serta pasien thalassemia untuk tetap hidup sehat dan rutin transfusi serta minum obat kelasi besi. Selain itu juga, sesama anggota POPTI Subang dalam hal ini orang tua dan pasien thalassemia saling bersilaturahmi serta membahas keluhan atau hambatan dalam pelayanan pengobatan pasien thalassemia di Rumah Sakit.

Penulis juga melakukan wawancara dengan perawat ruang thalassemia RSUD Kab.Subang (23 Mei 2019). Perawat tersebut mengatakan bahwa adanya POPTI sangat membantu dalam pendataan, menanggapi keluhan, dan penambahan fasilitas kesehatan. Namun, akhir-akhir ini peranan tersebut kurang dirasakan oleh pihak perawat RSUD Kab.Subang. Perubahan peran 
yang dilakukan POPTI tersebut berdampak pada pelayanan yang seharusnya diterima oleh anggota POPTI lainnya.

Secara administratif pasien dan orang tua pasien thalassemia memahami bagaimana aturan yang menjamin kesehatannya. Seperti mereka semua sudah terdaftar di asuransi kesehatan BPJS sehingga untuk seluruh pengobatannya dilaksanakan secara gratis. Dan juga seluruh pasien thalassemia yang berjumlah 128 orang sudah terdaftar di Popti, sehingga mempermudah dalam proses pengobatan di RSUD Kab.Subang ketika mendaftar.

Pemahaman pasien dan orang tua thalassemia bergantung pada informasi dan sosialisasi yang didapat. Sosialisasi ini memang tidak dapat berpangku pada popti saja, perlu adanya sosialisasi dari para aktor lain yang terlibat dalam implementasi kebijakan PNPK tata laksana thalassemia tersebut. Tindakan yang diberikan ketua popti ebagai penanggung jawab organisasi ialah memberikan sosialisasi point-point penting dan yang mudah diterima oleh pasien dan orang tua. Hal ini memberikan dampak poritif pada orang tua pasein untuk mengetahui hak dan kewajibannya.

Bila merujuk pada harapan semula, bahwa implemetasi kebijakan PNPK tata laksana thalassemia yang diberikan kepada pasien thalassemia untuk penanganan pasien dan mengurangi bertambahnya jumlah pasien. Dalam memberikan informasi bahwa tingkat pemahaman yang baru sebatas "tau" saja tidak cukup. Perlu adanya pemahaman mendalam mengenai hak dan kewajiban dari kebijakan PNPK tata laksana thalassemia.

Berdasarkan kebijakan PNPK tata laksanan thalassemia, didalamnya terdapat aktor-aktor yang terlibat untuk mengimplementasikan kebijakan tersebut. Diperlukan kerjasama dan kemitraan antara Rumah Sakit, PMI, Dinas Kesehatan, dan Popti. Namun yang terjadi dilapangan kerjasama ini belum terjalin dengan baik. Terkesan masing-masing menjalankan programnya saja.

Kesadaran masing-masing antara ketua dan anggota POPTI perlu dibangun kembali, sehingga peranan POPTI dalam membantu penanganan pasien dapat terlaksana sesuai dengan tujuan POPTI. Bergeraknya suatu 
organisasi dipengaruhi oleh sikap dari pemimpinnya. Hal ini juga mempengaruhi implementasi kebijakan publik menurut Smith (1973). Karena berhasil atau tidaknya suatu implementasi kebijakan di pengaruhi oleh kelompok sasaran. Kelompok sasaran digerakkan oleh seorang pemimpin yang perlu memiliki sikap kepemimpinan.

Berdasarkan hasil pengamatan peneliti, memang kurang kordinasinya antara anggota dan ketua POPTI subang. Ketua POPTI yang jarang terlihat di RSUD Subang dikarenakan anaknya tidak lagi berobat di RSUD Subang. Faktor ini juga diperkuat menurut perawat ruang thalassemia di RSUD Kab. Subang (23 Mei 2019), bahwa ketua POPTI sudah jarang mendatangi ruang thalassemia, seringnya anggota pasien yang mendatangi rumah ketua POPTI. Begitupula menurut salah satu orang tua pasien yang sedang berobat ke RSUD Subang mengatakan bahwa sekarangsekarang sudah jarang melihat ketua POPTI ke rumah sakit. Kurangnya perhatian POPTI subang ini dapat mempengaruhi pasien thalassemia dalam segi dukungan mental. Apalagi bagi pasien dan orang tua yang baru mengetahui anaknya menderita thalassemia perlu informasi mengenai penanganan anaknya.

Satu sisi POPTI tidak dapat bekerja sendirian dalam penanganan pasien ini, perlu adanya kerjasama dari pihak lain. Seperti dinas kesehatan dan pihak rumah sakit sebagai tempat pelayanan kesehatan. Kurangnya komunikasi dan kordinasi dari POPTI ini yang menjadi hambatan dalam implementasi kebijakan PNPK Tata Laksana Thalasemia.

\section{SIMPULAN}

POPTI merupakan organisasi perhimpunan orang tua penderita thalassemia Indonesia, anggotanya terdiri dari orang tua pasien thalassemia. Maksud dan tujuan dari organisasi ini ialah: meringankan beban orang tua penederita penyakit thalassemia, media komunikasi antara sesama orang tua penderita penyakit thalassemia, dan mengurangi meningkatnya penderita penyakit thalassemia, serta sebagai aktor untuk membantu pemerintah untuk penanganan pasien thalassemia.

$$
\text { Kebijakan publik yang }
$$
dikeluarkan untuk penanganan pasien thalassemia diatur dalam Keputusan Menteri Kesehatan Republik Indonesia 
Nomor HK.01.07/MENKES/1/2018

Tentang Pedoman Nasional Pelayanan

Kedokteran Tata Laksana Thalassemia (PNPK Tata Laksana Thalassemia). POPTI sebagai kelompok sasaran (target group) dalam implementasi kebijakan. Namun, implementasi dari kebijakan tersebut belum sepenuhnya berjalan dengan baik, khususnya peranan dari POPTI. Masih terdapat kendala komunikasi dan penggerak kepimimpinan dari pihak POPTI untuk membantu penanganan pasien thalassemia.

Dari simpulan tersebut, sekiranya terdapat beberapa hal yang perlu ditempuh POPTI untuk memperbaiki instasi. diperbaiki oleh POPTI. Pertama, para anggota POPTI perlu memiliki kesadaran bukan hanya sebagai penerima pelayanan, namun juga saling mendukung untuk penanganan pasien thalassemia, dalam hal ini orang tua pasien perlu meningkatkan pengawasan untuk memberikan obat serta transfusi darah sesuai aturan PNPK Tata Laksana Thalasemia. Sehingga diharapkan implementasi kebijakan keputusan menteri tersebut dapat berjalan dengan optimal.

Kedua, sebaiknya POPTI perlu melakukan kolaborasi antara anggota dan aktor terlibat lainnya dalam penanganan pasien, seperti pertemuan dengan pihak rumah sakit sebagi pelayanan kesehatan.

Keterbatasan pada penelitian ini ialah waktu. Saran pada peneliti selanjutnya untuk meneliti dimensidimensi lain seperti kebijakan ideal, organisasi pelaksana, dan faktor lingkungan dalam implementasi kebijakan PNPK Tata Laksana Thalassemia di Kabupaten Subang.

\section{DAFTAR PUSTAKA}

Anderson, James E. 2006. Public policy making: An Instroduction. Boston: Houghton Mifflin Company.

Harmoko. 2012. Asuhan Keperawatan Keluarga. Yogyakarta: Pustaka Pelajar

Howlett, Michael \& M. Ramesh. 1995. Studying public policy: Policy Cycles and Policy Subystems. Oxford: Oxford University Press.

Islamy, M. Irfan. 2001. Prinsip-prinsip Perumusan Kebijakan Negara. Jakarta: Bumi Aksara.

Mulyadi, Deddy. 2015. Studi Kebijakan dan Pekayanan Publik (Konsep dan Aplikasi Proses Kebijakan Publik dan Pelayanan Publik). Bandung: Alfabeta.

Parsons, Wayne.2006. Public Policy: Pengantar Teori dan Praktik Analisis Kebijakan. Jakarta: Kencana Prenada Media Group. 
Smith, Thomas B. 1973. The Policy Implementation Process. School of political science and public administration, Victoria university of Welington, New Zealand. Policy Sciences 4, pp 197-209.

Rusli, Budiman. 2013. Kebijakan Publik Membangun Pelayanan Publik yang Responsif. Bandung: Hakim Publisher.

Van Meter, D.S. dan C.E. Van Horn. 1975. The Policy Implementation Process: A Conceptual Framework. Administrastion \& Society. Ohio State University: SAGEpub.

Keputusan Menteri Kesehatan Republik Indonesia Nomor HK.01.07/MENKES/1/2018

Tentang Pedoman Nasional Pelayanan Kedokteran Tata Laksana Thalasemia. 